IJJM

Ilomata International Journal of Management

P-ISSN: 2714-8971; E-ISSN: 2714-8963

Vol. 1 No. 3 July 2020 pp.88-92

https://www.ilomata.org/index.php/ijim

\title{
Influence of Inflation on Poverty in Bima City
}

\author{
Junaidin $^{1}$, Puji Muniarty ${ }^{2}$ \\ ${ }^{12}$ Management Studies Program, Bima School of Economics, Bima City \\ Correspondent: puji.stiebima@gmail.com
}

Submitted : February 10, 2020 Revised : March 30, 2020 Published : July 30, 2020

\begin{abstract}
Inflation and poverty are important indicators in the economy, the pace and growth are always strived to be low and stable so as not to cause macroeconomic diseases which will later have an impact on instability on the economy. This study aims to analyze the effect of independent variables on the dependent variable. The independent variable in this study is inflation while the dependent variable is poverty in the City of Bima in the period 2013-2018. The sample in this study is in the form of inflation and poverty data for the past 6 years, namely from 2013 to 2018. The data used in this study are in the form of a list of tables regarding inflation and poverty for 6 years obtained from the Office of the Statistics Indonesia (BPS) office in Bima City. The data used are secondary data and the method used is simple linear regression analysis, simple correlation coefficient, simple linear determination and t-test (2 parties) using SPSS Version 20.0 to get a comprehensive picture of the relationship between one variable with another variable. The results showed that inflation had no effect and was not significant on poverty in Bima City.
\end{abstract}

\section{INTRODUCTION}

Bima City is an autonomous city located on the island of Sumbawa, West Nusa Tenggara province, in general, the city has economic problems such as poverty and high inflation rates. The high level of inflation is an important indicator in an economy that cannot be ignored, its rate and growth are always strived to be low and stable so as not to cause macroeconomic diseases which will later have an impact on instability in the economy.

Referring to the current economic conditions the condition of the prices of goods and services, in generals continuously not only on one item but the price increase that occurs in several types of goods consumed by the public. With price increases that occur not just for a moment but can occur within a static period of time.

High and unstable inflation is a reflection of economic instability that results in rising prices of goods and services continuously and results in higher poverty in Bima City. Based on data from the Statistics Indonesia (BPS) of Bima City in the last 6 years, Inflation in Bima City from 2013 to 2018 experienced fluctuations in which every year is changing. In 2013 inflation in Bima City was $10.06 \%$ while in 2014 it decreased by $2.79 \%$ than in 2015 it decreased by $2.87 \%$, then in 2016 it decreased again by $1.19 \%$, after that in the year 2017 increased by $0.94 \%$, then in 2018 it increased again by $1.53 \%$ due to price increases as indicated by an increase in the index in certain foodstuff groups.

Observing the fluctuating inflation movement above is expected to affect poverty in Bima City. As with other regions that inflation is controlled by the local government through fiscal and monetary policies so that it can stabilize the price of goods consumed by the community resulting in increased purchasing power of consumers or the community in general and reduce poverty. The 


\section{Influence of Inflation on Poverty in Bima City}

Junaidin \& Muniarty

existence of inflation along with poverty has become a very common problem faced, almost in every region in Indonesia has almost the same problem, namely poverty. The poverty that occurs in an area becomes a benchmark for an area to see the pros and cons of a regional economy. Poverty is not only a personal and government problem, but it is also a problem that we all need to suppress.

According to Fikri (2016), poverty is not only understood as an economic inability but failure to fulfill basic rights and differences in treatment for a person or group of people living their life with dignity. Basic rights recognized in general include the fulfillment of food, health, employment, housing, clean water, land, natural resources, environment and security from the threat of violence.

One cause of poverty is due to lack of income and assets to meet basic needs such as food, clothing, housing and the level of health and education that can be received. Besides poverty also associated with limited employment and usually they are categorized as poor do not have a job (unemployment), and their education and health levels are generally inadequate. Overcoming the problem of poverty cannot be done separately from the problem of unemployment, education, health and other problems that are explicitly related to the problem of poverty.

Poverty is one of the diseases in the economy, so it must be cured or at least reduced in number amount. Poverty is a very complex and multidimensional problem. Therefore, poverty alleviation efforts must be carried out comprehensively, covering various aspects of community life, and carried out in an integrated manner. Based on data from the Statistics Indonesia (BPS) of Bima City, Poverty in Bima City from 2013-2018 experienced fluctuations. in 2013 poverty in the city of Bima reached $9.06 \%$ which then declined in 2014 to $9.74 \%$. Furthermore, in 2015 there were $9.85 \%$ of the poor population in Bima City, an increase of $0.11 \%$ from 2014 . The increase in the poor population was due to an increase in inflation and prices for necessities as well as inequality in the consumption / income distribution. From this explanation raises the question whether inflation has a significant effect on poverty in Bima City. The purpose of this study is to determine whether there is a significant effect of inflation on poverty in Bima City.

The results of previous studies conducted by (Imelia, 2012) show that inflation does not have a significant effect on poverty in Jambi province. Supported by other studies, Indonesian inflation has a positive effect on poverty in Indonesia. So that researchers are interested in researching with the title effect of inflation on poverty in Bima City.

\section{METHOD}

This research was conducted in Bima City, the research design used was a causal research design that is a research design that was conducted to determine the effect or causal relationship between the independent variable and the dependent variable. So we can know the characteristics of the relationship between the cause and effect variables that will be reduced by using a quantitative approach. Quantitative research is research that concentrates on testing theories through variables in the form of numbers and then doing data analysis with statistical processes either manually or computer software. This type of research is classified as associative research. Associative research is a statement that shows allegations about the relationship between two or more variables (Sugiyono, 2017: 89). The research variables to be examined in this study are divided into two main variables, namely the independent variable $(\mathrm{X})$ consisting of inflation and the dependent variable, namely poverty $(\mathrm{Y})$. The purpose of this study was to look for the effect of inflation $(\mathrm{X})$ on poverty $(\mathrm{Y})$ in Bima City. 


\section{Influence of Inflation on Poverty in Bima City}

Junaidin \& Muniarty

The population in this study is inflation and poverty data for 8 years, from 2001 to 2018. The sampling technique used by the author is nonprobability sampling using purposive sampling based on consideration of the availability of the data obtained and the use of new / updated data. As for the sample in this study is in the form of inflation and poverty data for the last 6 years, namely from 2013 to 2018. Data collection techniques in this study are observation, interviews, documentation and library research, when the research was conducted for 3 months starting from December 2019 until February 2020. Below is the percentage table of inflation and poverty from 2013-2018 .

Figure 1: Inflation and Poverty Development in Bima City in 2013-2018

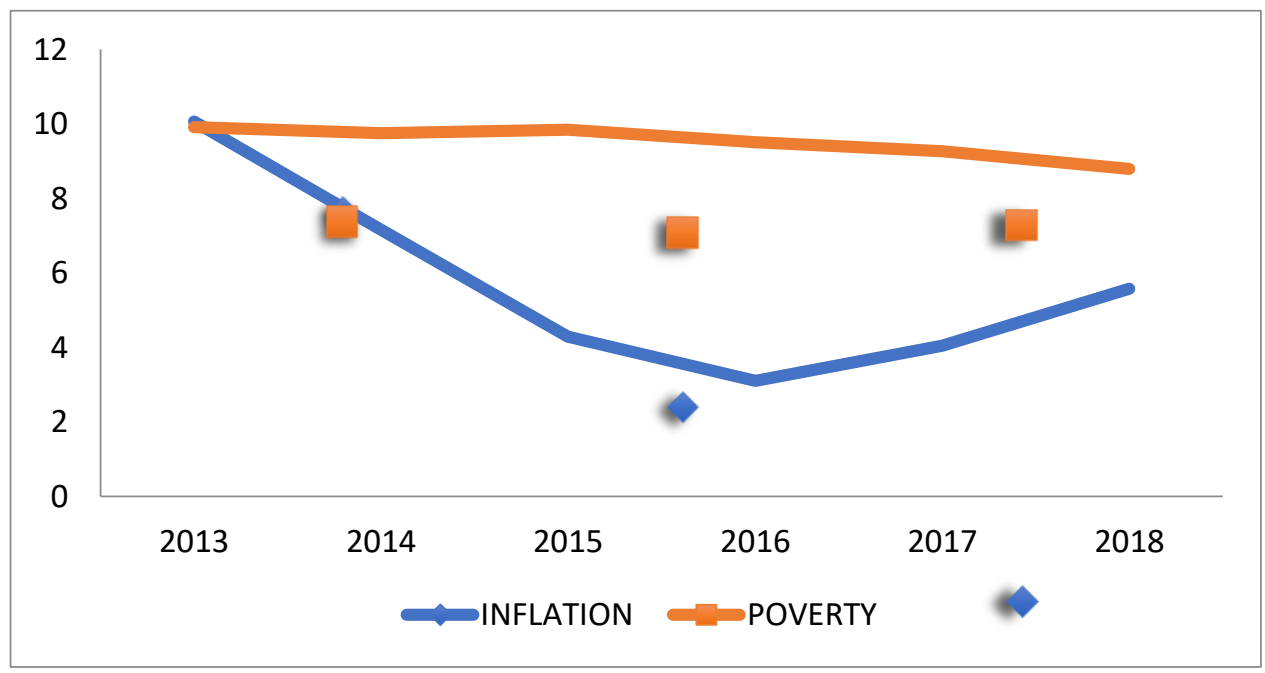

Source: BPS Bima City

The analysis techniques used in this study are inflation analysis techniques, poverty analysis techniques, simple linear regression analysis techniques, simple correlation coefficients, simple linear determination and t test ( 2 parties) to obtain a comprehensive picture of the relationship between one variable with another variable. The portrait of the effect of inflation on poverty is theoretically unidirectional, meaning that the increase in inflation will be reflected in an increase in the price of goods and services available in an area, which causes a decrease in purchasing power, this will have implications for decreasing welfare or prosperity of the community, which means increasing poverty.

\section{RESULT AND DISCUSSION}

Table 1. Simple Linear Regression Analysis

Coefficients $^{\mathrm{a}}$

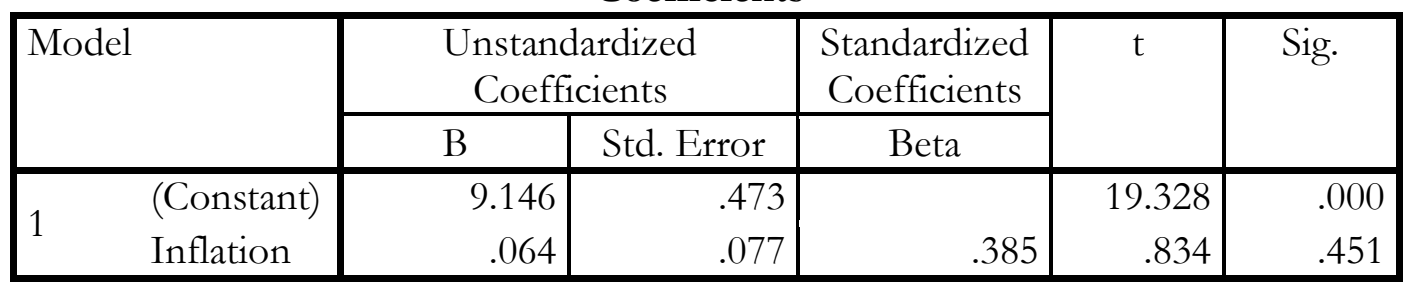

a. Dependent Variable: POVERTY

Source of Data: Output Spss Versi 20.0, 2019

Based on SPSS output in version 20.0, the regression equation can be made as follows:

$$
\mathrm{Y}=9,146+0.064 \mathrm{X}
$$


Influence of Inflation on Poverty in Bima City

Junaidin \& Muniarty

The above equation has the meaning:

1. Constant (a) $=9,146$ if inflation is constant or equal to zero then poverty in Bima City will increase by 9,146 .

2. Regression coefficient (b) $=0.064$ if inflation is Rp. 1 or $1 \%$, the poverty in Bima City is 0.064

Based on the SPSS output in version 20.0, a t-count value of 0.834 and a significance level of 0.451 are obtained. Then compared with t-table, by conducting two-way testing at $\boldsymbol{\alpha} / 2=0.05$ $/ 2=0.025$ and degrees of freedom $(\mathrm{df})=\mathrm{n}-\mathrm{k}$ where $" \mathrm{k}$ " is the number of free and bound variables $=2$, then $\mathrm{dk}=6-2=4$. So we get the t-table value of 2.776 . From these results, the value of sig. $>0.05(0.451>0.05)$ which indicates that inflation has no significant effect on poverty in Bima City.

Table 2. Model Summary

Model Summary

\begin{tabular}{|l|l|l|l|l|}
\hline Model & $\mathrm{R}$ & $\mathrm{R}$ Square & $\begin{array}{l}\text { Adjusted R } \\
\text { Square }\end{array}$ & $\begin{array}{l}\text { Std. Error of the } \\
\text { Estimate }\end{array}$ \\
\hline 1 & $.385^{\mathrm{a}}$ & .148 & -.065 & .43887 \\
\hline
\end{tabular}

a. Predictors: (Constant), INFLATION

Source of Data: Output Spss Versi 20.0, 2019

Based on the SPSS output in version 20.0, a correlation value of 0.385 is obtained, which means that the level of closeness of the relationship between inflation and poverty in Bima City is at a moderate level. The Determination Coefficient $\left(\mathrm{R}^{2}\right)$ value of 0.148 means that the influence of inflation on poverty in Bima City is $14.8 \%$, while the remaining $85.2 \%$ is influenced by other factors not examined in this study.

\section{CONCLUSION}

Based on research and statistical calculations that have been described previously, the t-value is smaller than the t-table value with a significance $>0.05$. This shows that there is no significant effect of inflation on poverty in the city of Bima. Thus Ho is accepted and $\mathrm{Ha}$ is rejected.

The analysis shows that the poverty rate in Bima City from 2013-2018 experienced a fluctuation with the highest poverty percentage that occurred in 2013 of $9.91 \%$ and the lowest poverty occurred in 2018 of $8.79 \%$. Whereas the highest inflation in 2013 was $10.06 \%$. While the lowest inflation occurred in 2016, down 1.19\% from 2015. Influence of Inflation on poverty in Bima City where the inflation variable does not effect and is not significant on this poverty variable shows there are other variable factors not examined in this study. The results of this study can be used as a reference for researchers to learn about the effects of inflation on poverty.

Based on the research results and conclusions obtained, the suggestions that can be given by researchers in this study are as follows: (1) The government must make a policy and take a large enough role to be able to encourage the achievement of better and more advanced economic growth by increasing the community's production capacity to reduce the number of poor people in Bima City so that it can reduce poverty in Bima City. (2) It is expected that the Bima city government can increase economic growth for regions whose economic growth has not yet contributed to the economy in Bima City which can increase community productivity through increased budget allocations for education to enhance work quality, provide skills training for the community and expand employment opportunities so that output is increasing and in the end can spur economic growth in the city of bima. (3) It is expected that the government of Bima City will 


\section{Influence of Inflation on Poverty in Bima City}

Junaidin \& Muniarty

carry out poverty reduction efforts. Then move the economic sectors so that they contribute more to economic growth in the City of Bima, so they can absorb labor.

\section{REFERENCE}

Imelia. (2012). Pengaruh Inflasi Terhadap Kemiskinan Di Propinsi Jambi. Jurnal 92aradigm ekonomika 1(5) : 42- 48.

Ningsi D. (2018). Analisis Pengaruh Inflasi Dan Pertumbuhan Ekonomi Terhadap Kemiskinan Di Indonesia. Jurnal samudra ekonomika 2(1) : 53-61.

Sugiartiningsi, Khaerul S. (2017). Pengaruh Inflasi Terhadap Kemiskinan Di indonesia. Proceedings Profesionalisme Akutan Sustainable Bisiness Practice: 518-526. Bandung, 20 Juli 2017: Universitas Widyatama.

Susanto E, Rochaida E, Ulfah Y. (2017). Pengaruh Inflasi Dan Pendidikan Terhadap Pengangguran Dan Kemiskinan. Journal.feb.Ummul.Ac.Id/Indekx.Php/INOVASI, Volume 12 Nomor 1 hal. 19- 27.

Pratama, Yogi C. (2014) Analisis Faktor Yang Mempengaruhi Kemiskinan Di Indonesia. Jurnal Bisnis Dan Manajemen, UIN Syarif Hidayahtullah Jakarta.

Susanto E, Rochaidah E, Yana Ulfha. 2017. "Pengaruh Inflasi Dan Pendidikan Terhadap Pengangguran dan Kemiskinan". Jurnal Fakultas Ekonomi dan Bisnis UNMUL. Vol.13 No.1, hlm. 19-27.

Sofyan, M. (2019). Faktor-Faktor Yang Mempengaruhi Profitabilitas Bank Perkreditan Rakyat (BPR) di Provinsi Jawa Timur. Jurnal Inspirasi Bisnis dan Manajemen, 3(1), 63-76. doi:10.33603/jibm.v3i1.2093.

Sugiyono. (2017). Metode Penelitian Kualitatif, Kuantitatifdan R \&D. Alfabeta:Bandung.

Wahyu Utomo, Fajar. (2013). "Pengaruh Inflasi dan Upah Terhadap Pengangguran di Indonesia Periode Tahun 1980-2010". Jurnal Fakultas Ekonomi dan Bisnis Universitas Brawijaya. 